\title{
Nutritional ecology provides insights into competitive interactions between closely-related marten species
}

\author{
Andrea Gazzola and Alessandro Balestrieri* \\ Department of Earth and Environmental Sciences, University of Pavia, Via Ferrata 9, 27100 Pavia, Italy \\ * Corresponding author, alebls@ libero.it
}

\begin{abstract}
For generalist, closely-related predators as those belonging to the genus Martes, it is a hard task to differentiate the effects on feeding habits of variation in food availability from those of resource competition. To overcome this obstacle, we reviewed dietary studies that assessed the relative bulk of each food item, as either percent biomass or percent mean volume, in the diet of both the pine(M. martes) and stone- (M. foina) marten, and calculated the nutrient profiles (intakes of protein, lipids and carbohydrates, expressed as percentages of total metabolizable energy) of each diet. Both martens' diets tightly clustered (average values: 47\% protein-, 39\% lipid- and 14\% carbohydrate energy), but, most interestingly, in allopatry the nutritional niches of the two species did not differ, while the stone marten ate more carbohydrates and less protein when sympatric with the pine marten. Our data suggest that stone marten frugivory is the result of interspecific competition.
\end{abstract}

Key words: macronutrients, intake target, resource competition, Martes sp.

\section{Introduction}

Pine marten Martes martes and stone marten Martes foina are the most similar European carnivores (see [1]) and co-exist over a large area, including most of central and southern Europe [2]. While forested habitats are key-features for both species, the stone marten often occurs in rural and suburban areas $[3,4]$. This association with human-dominated habitats has been explained as the result of competition with the pine marten [5], and may be enhanced by stone marten's higher tolerance towards human disturbance [6]. Nonetheless, in the last two decades the pine marten has been reported to occur also in rural $[7,8]$ and even intensively cultivated areas $[9,10]$.

Although spatial segregation should entail the use of partially different food resources [11,12], the two martens' trophic niches overlap extensively $[13,14]$. Both species are generalist feeders, using a large variety of food items, with small mammals and fruit often forming the bulk of their diets (reviewed by [15-18]). These diverse feeding habits make it hard to compare the food preferences of the two martens at range scale. Moreover, as their faeces cannot be distinguished by eye, the diets of the two martens have mostly been studied separately, preventing from differentiating the effects of local and temporal variation in food availability from those of interspecific (or intra-guild) competition [13].

Recently, Machovsky-Capuska et al. [19] suggested that a deeper insight into feeding ecology can be obtained by a multidimensional approach, integrating the percentage contribution of food items to diets with their nutritional composition. Animals typically regulate the amounts and balance of macronutrients (i.e. protein, lipids and carbohydrates) in their diets by either selecting nutritionally balanced foods or combining complementary foods to achieve a species-specific macronutrient intake target $[20,21,22]$. Previously confined to laboratory experiments with captive animals and controlled diets, the assessment of the macronutrient composition of meso-carnivore diets has been demonstrated to be achievable by the analysis of stomach contents or faecal samples from wildliving animals [23]. Till now this indirect method has been successfully applied to a handful of species, including the pine marten [24]. 
We hypothesized that macronutrient gains may enable us to compare the feeding requirements of the pine-and stone martens independently from the way their populations respond to various food availabilities and thus more effectively than by classical estimates of trophic niche overlap at foodlevel. To test for this hypotheses, we reviewed available data on the foods eaten by pine- and stone marten populations across Europe and estimated the percentage of macronutrients in each diet to quantify and compare their nutritional niches.

\section{Methods}

We selected those studies that assessed, as either per cent biomass or per cent mean volume, the relative bulk of each food item in marten diet by the analysis of either stomach or faecal samples. Minimum sample size was set at $60[17,24]$ and studies had to cover at least one complete year. When only seasonal data were reported, the mean annual relative bulk of each food item was calculated a posteriori. Available literature (e.g. [23,25,26]) and on-line databases (e.g. https://ndb.nal.usda.gov/; www.valori-alimenti.com) were checked to obtain, on a wet weight basis, the macronutrient composition (mean percentage of protein, lipids, and carbohydrates) of the food items used by martens (Tab. S1).

Nutrient profiles were calculated following Remonti et al. [23,24] and expressed as percentages of total metabolizable energy $(\mathrm{kcal})$ using the following coefficients: protein $=14.64 \mathrm{~kJ} / \mathrm{g}$; fat $=35.56$ $\mathrm{kJ} / \mathrm{g}$; non-structural carbohydrates $=14.64 \mathrm{~kJ} / \mathrm{g}[27,28]$. Macronutrient compositions of martens' selected diets were visualized by equilateral mixture triangles (EMTs), which allow to represent 3components (i.e. protein, lipids and carbohydrates) in a two-dimensional nutrient space [27].

To assess the effects of interspecific competition on macronutrient intakes, data were split into four groups, resulting from range overlap (sympatry $v s$. allopatry).

Finally, based on the description of study areas in selected studies, data were also split in three habitat types, broadly arranged along a gradient of increasing human interference: i) temperate forests or Mediterranean shrubland; ii) forest (shrubland) - agricultural mosaics; iii) agricultural areas.

Nutritional niche overlap between pine- and stone marten was assessed by dynamic range boxes (dynRB; [29]), a non-parametric, robust approach for analysing compositional data [30]. Trait space overlap port $(a, b)$ was calculated by the aggregation methods "product", which calculates the geometric volume delineated by the interval lengths of each dimension of Hutchinson's hypervolume (the sides of the boxes), and "mean" (of the side lengths), which assesses how similar two niches are based on the mean overlap of the $n$ dimensions [29]. Data analyses were performed using R package dynRB [31].

Macronutrient intakes were then compared by permutational multivariate analysis of variance (PERMANOVA; [32]) with 10000 permutations. Analyses were performed in R (3.5.1 version), with the package "vegan" [33]. Mann-Whitney $(U)$ or Kruskal-Wallis tests were used as post-hoc tests to compare single nutrients, while raw frequency data of food items in the two diets were compared by the chi-squared $\left(\chi^{2}\right)$ test.

\section{Results}

Thirty-two studies (mean sample size: 507.7, min-max: 73-2449) were selected (Tab. S1), covering the two martens' European ranges from Portugal in the west to Belarus in the east and from Sweden in the north to southern Spain (Fig. S1).

Mammals, particularly small rodents and insectivores, and fruit formed the bulk of both marten diets, followed by birds. The contribution of major food items to marten diets varied largely (small mammals: $7-81.2 \%$ for the stone marten and $15.5-74.8 \%$ for the pine marten; fruit: $9-63.5 \%$ and 3$54 \%$, respectively). The total number of mammal prey recorded was 41 (stone marten: 33; pine 
marten: 27), with the pine marten relying on large mammals more frequently than the stone marten $\left(\chi^{2}=4.41, p=0.03\right)$, which, on its turn, ate more synanthropic rodents $\left(\chi^{2}=5.5, p=0.02\right)$. Both martens used a large variety of fruits (34 species, 29 for the stone marten and 22 for the pine marten), with the stone marten eating cultivated species more often than the pine marten $\left(\chi^{2}=31.3\right.$, $p<0.001)$.

Mean $( \pm$ SE) macronutrient intakes (Tab. S2; Fig. 1) were $48.9 \pm 1.5 \%$ protein-, $40.3 \pm 0.8 \%$, lipidand $10.8 \pm 1.9 \%$ carbohydrate energy for the pine marten and $44.4 \pm 1.7 \%$ protein-, $37.0 \pm 1.3 \%$, lipid- and $18.6 \pm 2.6 \%$ carbohydrate energy for the stone marten. Lipid- and carbohydrate intakes differed significantly between species $(U=59.0, p=0.011$ for both), nonetheless the average protein:lipid ratio did not differ (1.22 \pm 0.03 and $1.21 \pm 0.04$, respectively).

The largest divergence in nutritional niches occurred between allopatric and sympatric stone martens, while, on the opposite, pine marten niches overlapped almost completely (Fig. 2A). The niche of allopatric pine marten overlapped that of allopatric stone marten to a larger extent that the opposite ( $a$ over $b$ vs $b$ over $a$ ), consistently with allopatric stone marten showing the smallest niche size (Fig. S2). The aggregation method "mean" pointed out that the overlaps between the trait spaces of sympatric pine- and stone marten and vice-versa were intermediate and nearly symmetric (Fig. 2B). Accordingly, analysis of variance showed that pine marten macronutrient intake did not vary between allopatry and sympatry $(F=0.001, p=0.91)$, while, on average, the stone marten consumed less protein and more carbohydrates in sympatry $(F=7.25, p=0.02$; Tab. 1; Fig. 1$)$. The average macronutrient compositions of the two martens' diets in allopatry did not differ $(F=0.69, p$ $=0.54$; Tab. 1$)$, while differed in sympatry $(F=8.17, p=0.01)$.

Most studies on pine marten $(77.8 \%)$ were carried out in forests, preventing from comparing diets at habitat-level, while no significant difference was recorded in the macronutrient intakes of stone martens living in different habitats (Kruskal-Wallis test, $\chi^{2}=0.1-0.6 ; p>0.7$ for all tests).

\section{Discussion}

Despite we reviewed literature studies which aimed to assess the relative importance of food items rather than macronutrient intakes, and inevitably varied in the type and quality of laboratory procedures, the diets of both martens tightly clustered. The similarity in the macronutrient composition of a large variety of diets throughout the wide European range of each species confirms that both martens tend to balance their nutrient intake by combining available food resources appropriately.

Most importantly, we demonstrated that in allopatry the nutritional niches of the two species do not differ, an achievement previously hindered by between-species differences in diet composition due to geographic variation in food availability. Our results suggest that these two mustelids, extremely similar in size, physiology and hunting strategies, also share almost identical nutrient requirements. While sympatry does not seem to involve significant deviations from the macronutrient intake target of the pine marten, we recorded an increase in the percent contribution of carbohydrates (i.e. fruit) in the diet of the stone marten, to the detriment of protein gain. Dietary shift in the stone marten may depend on two alternative mechanisms: 1) higher tolerance to carbohydrates respect to the pine marten, which would imply a larger variety of food items potentially exploitable (second and third level, respectively, of the nutritional niche size proposed by Machovsky-Capuska et al. [19]), or 2) higher competitive ability of the pine marten, which would force the stone marten to use less suitable foods.

The first hypothesis is not supported by available data: high carbohydrate levels have been reported also for the pine marten, in habitats that can be regarded as sub-optimal for this species [24,34,35]. Moreover, while the pine marten was reported to be the least frugivorous mesocarnivore of Mediterranean Europe [36], our review has pointed out that both martens can use a large variety of berries. 
The competition hypothesis is consistent with the capacity of the pine marten to exclude the stone marten from forested habitats, which has been suggested by Delibes [5] as evidence of pine marten dominance. Spatial segregation per se can affect diet composition, by giving access to different food resources. As an example, in agricultural areas, cereals provide one-third of the protein intake of European badgers (Meles meles), with the consequence of an increase in carbohydrate consumption with respect to forested habitats [23]. The use of cultivated fruit and synanthropic rodents by the stone marten clearly reflects its occurrence in anthropogenic habitats (as so as pine marten's preference for large mammals depends on its more northern range; [16]). Nonetheless, the average macronutrient balance of the stone marten did not vary among habitats, suggesting that diet shift may also result from fine-grained adjustments in the use of space (e.g. use of less suitable, in terms of food availability, but pine marten-free food patches; see [37]) or differential use of food resources in overlapping hunting areas [38]. Accordingly, in allopatry the protein intake of the stone marten was high (45-52\%) in very different habitats, from intensively cultivated lowland to Alpine forests and Mediterranean scrubland. Interestingly, at the southern edge of pine marten range, the pattern of dominance is reversed and the pine marten is more frugivorous than the more abundant and spread stone marten [35], supporting the role played by interspecific competition in shaping the diet of these mustelids. However, dynRB aggregation method "mean" suggests that diet shifts do not differentiate the nutritional niches of sympatric marten species to the extent necessary to prevent competition, implying that co-existence is the results of a mosaic of behavioural adjustments, including habitat- [4] and time-partitioning [39].

For the first time, nutritional ecology provided evidence that stone marten frugivory may be, at least partially, a makeshift strategy to cope with competition with the pine marten, rather than the result of the selection for a highly profitable resource. To paraphrase Rosenzweig [40], from a macronutrient perspective the stone marten would do better, on average, investing its time and energy to pursue protein-rich small vertebrates than searching for fruit, but this alternative food resource may enhance its coexistence with the pine marten throughout Europe. We argue that our approach may contribute to understand the feeding strategies of other closely-related sympatric species, provided that dietary studies are fostered and data expressed in terms of volume or biomass. 


\section{References}

1. Larroque J, Ruette S, Vandel J-M, Devillard S 2015 Where to sleep in a rural landscape? A comparative study of resting sites pattern in two syntopic Martes species. Ecography 38, 112.

2. Mitchell-Jones AJ, Amori G, Bogdanowicz W, Krystufek B, Reijnders PJH, Spitzenberger F, Stubbe M, Thissen JBM, Vohralik V, Zima J 1999 The atlas of European mammals. London: Poyser Natural History Academic.

3. Virgós E, Zalewski A, Rosalino LM, Mergey M 2012 Habitat ecology of genus Martes in Europe: a review of the evidences. In: Aubry KB, Zielinski WJ, Raphael MG, Proulx G, Buskirk SW (eds) Biology and conservation of marten, sables, and fisher: a new synthesis. New York: Cornell University Press, pp. 255-266.

4. Vergara M, Cushman SA, Madeira MJ, Ruiz-González A 2017 Living in sympatry on the edge: Assessing distribution, habitat suitability and niche partitioning for pine and stone marten (Martes martes and Martes foina) in the Iberian Peninsula. In: Zalewski A, Wierzbowska IA, Aubury KB, Birks JDS, O'Mahony DT, Proulx G (eds) The Martes complex in the 21st Century: Ecology and Conservation. Białowieża: Mammal Research Institute \& Polish Academy of Science.

5. Delibes M 1983 Interspecific competition and the habitat of the stone marten Martes foina (Erxleben, 1777) in Europe. Acta Zool. Fenn. 174, 229-231.

6. Balestrieri A, Mori E, Menchetti M, Ruiz-González A, Milanesi P 2019 Far from the madding crowd: Tolerance towards human disturbance shapes distribution and connectivity patterns of closely related Martes spp. Popul. Ecol.

7. Pereboom V, Mergey M, Villerette N, Helder R, Gerard JF, Lodé T 2008 Movement patterns, habitat selection, and corridor use of a typical woodland-dweller species, the European pine marten (Martes martes), in a fragmented landscape. Can. J. Zool. 86, 983991.

8. Mergey M, Helder R, Roeder J-J 2011 Effect of forest fragmentation on space-use patterns in the European pine marten (Martes martes). J. Mammal. 92, 328-335.

9. Balestrieri A, Ruiz-González A, Capelli E, Vergara M, Prigioni C, Saino N 2016 Pine marten $v s$. stone marten in agricultural lowlands: a landscape-scale, genetic survey. Mamm. Res. 61, 327-335.

10. Balestrieri A, Remonti L, Ruiz-González A, Gómez-Moliner BJ, Vergara M, Prigioni C 2010 Range expansion of the pine marten (Martes martes) in an agricultural landscape matrix (NW Italy. Mamm. Biol. 75, 412-419.

11. Marchesi P, Lachat N, Lienhard R, Debieve PH, Mermod C 1989 Comparaison des régimes alimentaires de la fouine (Martes foina Erxl) et de la martre (Martes martes L) dans une région du Jura suisse. Rev. Suisse Zool. 96, 127-146.

12. Lanszki J 2003 Feeding habits of stone martens in a Hungarian village and its surroundings. Folia Zool. 52, 367-377.

13. Posluszny M, Pilot M, Goszczynski J, Gralak B 2007 Diet of sympatric pine marten (Martes martes) and stone marten (Martes foina) identified by genotyping of DNA from faeces. Ann. Zool. Fenn. 44, 269-284.

14. Remonti L, Balestrieri A, Ruiz-González A, Gómez-Moliner BJ, Capelli E, Prigioni C 2012 Intraguild dietary overlap and its possible relationship to the coexistence of mesocarnivores in intensive agricultural habitats. Popul. Ecol. 54, 521-532.

15. Clevenger A 1994 Feeding ecology of Eurasian pine marten Martes martes and stone marten Martes foina in Europe. In: Buskirk S, Harestad A, Raphael M, Powell R (eds) Martens, Sables and Fishers: Biology and Conservation. New York: Comstock Publishing Associates Ithaca, pp. 326-340.

16. Zalewski A 2004 Geographical and seasonal variation in food habits and prey size of European Pine Marten. In: Harrison DJ, Fuller AK, Proulx G (eds) Martens and Fishers 
(Martes) in Human-Altered Environments. An International Perspective. New York: Springer Science and. Business Media Inc., pp. 77-98.

17. Zhou Y-B, Newman C, Xu W-T, Buesching CD, Zalewski A, Kaneko Y, Macdonald DW, Xie Z-Q 2011 Biogeographical variation in the diet of Holarctic martens (genus Martes, Mammalia: Carnivora: Mustelidae): adaptive foraging in generalists. J. Biogeogr. 38, 137147.

18. Papakosta M, Kitikidou K, Bakaloudis D, Vlachos C 2014 Dietary Variation of the Stone Marten (Martes foina): A Meta-Analysis Approach. Wildl. Biol. Pract. 10, 85-101 (doi:10.2461/wbp.2014.10.11).

19. Machovsky-Capuska GE, Senior AM, Simpson SJ, Raubenheimer D 2016 The Multidimensional Nutritional Niche. Trends Ecol. Evol. 31, 355-365.

20. Raubenheimer D, Simpson SJ 1997 Integrative models of nutrient balancing: application to insects and vertebrates. Nutr. Res. Rev. 10, 151-179.

21. Raubenheimer D, Simpson SJ 2003 Nutrient balancing in grasshoppers: behavioural and physiological correlates of dietary breadth. J. Exp. Biol. 206, 1669-1681.

22. Raubenheimer D, Simpson SJ 2003 Unravelling the tangle of nutritional complexity. Wissenschafts kollegzu Berlin, Jahrbuch vol 2002/2003, 275-294.

23. Remonti L, Balestrieri A, Prigioni C 2011 Percentage of protein, lipids, and carbohydrates in the diet of badger (Meles meles) populations across Europe. Ecol. Res. 26, 487-495 (doi: 10.1007/s11284-011-0804-9).

24. Remonti L, Balestrieri A, Raubenheimer D, Saino N 2016 Functional implications of omnivory for dietary nutrient balance. Oikos 125, 1233-1240.

25. Fidanza F, Versiglioni N 1989 Tabelle di composizione degli alimenti. Istituto di Scienza dell'Alimentazione. Napoli: Idelson Ed.

26. Colli A, Rossi P, Marzatico F 2006 Viaggio negli alimenti. Tabelle di composizione chimica e valore energetico degli alimenti. Bologna: Calderini.

27. Raubenheimer D 2011 Toward a quantitative nutritional ecology: the right-angled mixture triangle. Ecol. Monogr. 81, 407-427.

28. Hewson-Hughes AK, Hewson-Hughes VL, Miller AT, Hall SR, Simpson SJ, Raubenheimer D 2011 Geometric analysis of macronutrient selection in the adult domestic cat, Felis catus. J. Exp. Biol. 214, 1039-1051.

29. Junker RR, Kuppler J, Bathke AC, Schreyer ML, Trutschnig W (2016) Dynamic range boxes - A robust non-parametric approach to quantify size and overlap of $\mathrm{n}$ dimensional hypervolumes. Methods Ecol Evol. 7, 1503-1513.

30. Brückner A, Heethoff M 2017 A chemo-ecologists' practical guide to compositional data analysis. Chemoecol. 27, 33-46.

31. Schreyer M, Trutschnig W, Junker RR, Kuppler J, Bathke A, Parkinson JH, Kutil R 2018 dynRB: Dynamic Range Boxes V. 0.15. https://CRAN.R-project.org/package=dynRB.

32. Anderson MJ 2001 A new method for non-parametric multivariate analysis of variance. Austral. Ecol. 26, 32-46.

33. Oksanen J, Blanchet GF, Friendly M, Kindt R, Legendre P, McGlinn D, Minchin PR, O'Hara RB, Simpson GL, Solymos P, Stevens MHH, Szoecs E, Wagner H 2013 Package 'vegan' 2.9.

34. Lynch AB, McCann Y 2007 The diet of the pine marten (Martes martes) in Killarney National Park. Proc. R. Irish Acad. Biol. Environ. 107B, 67-76.

35. Monterroso P, Rebelo P, Alves PC, Ferreras P 2016 Niche partitioning at the edge of the range: a multidimensional analysis with sympatric martens. J. Mammal. 97, 928-939.

36. Rosalino LM, Santos Reis M 2009 Fruit consumption by carnivores in Mediterranean Europe. Mammal Rev. 39, 67-78. 
37. Wereszczuk A, Zalewski A 2015 Spatial Niche Segregation of Sympatric Stone Marten and Pine Marten - Avoidance of Competition or Selection of Optimal Habitat? PLoS ONE 10(10), e0139852.

38. MacArthur R, Levins R 1964 Competition, habitat selection, and character displacement in a patchy environment. Zoology 20, 1207-1210.

39. Torretta E, Mosini A, Piana M, Tirozzi P, Serafini M, Puopolo F, Saino N, Balestrieri A 2017 Time partitioning in mesocarnivore communities from different habitats of NW Italy: insights into martens' competitive abilities. Behaviour 154, 241-266.

40. Rosenzweig ML 1966 Community Structure in Sympatric Carnivora. J. Mammal. 47, 602612. 
Table 1. Average macronutrient intakes of pine- and stone martens occurring in either allopatry or sympatry.

\begin{tabular}{llccc}
\hline Species & Range & Protein & Lipids & Carbohydrates \\
\hline \multirow{3}{*}{ Pine marten } & allopatry & 49.3 & 40.4 & 10.3 \\
& sympatry & 48.7 & 40.2 & 11.1 \\
& & $U=34.0, p=0.68$ & $U=38.0, p=0.96$ & $U=38.0, p=0.96$ \\
\multirow{3}{*}{ Stone marten } & allopatry & 49.4 & 38.7 & 11.8 \\
& sympatry & 42.5 & 36.4 & 21.1 \\
& & $U=4.0, p=0.01$ & $U=17.0, p=0.37$ & $U=7.0, p=0.03$ \\
\hline
\end{tabular}



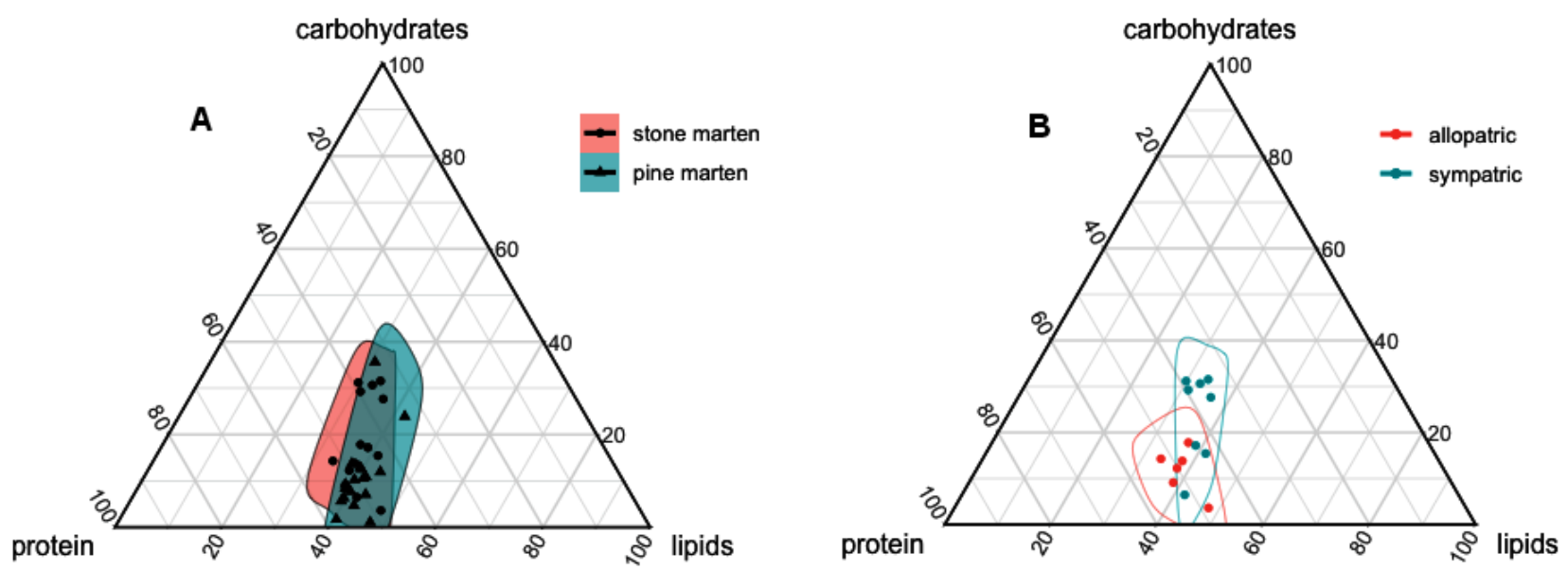

Figure 1. Equilateral mixture triangle showing the estimated macronutrient intake of A) pine- and stone martens from 32 European sites, and B) the stone marten living in either allopatry or sympatry with the closely-related pine marten. Data are expressed as percentage of metabolizable energy.
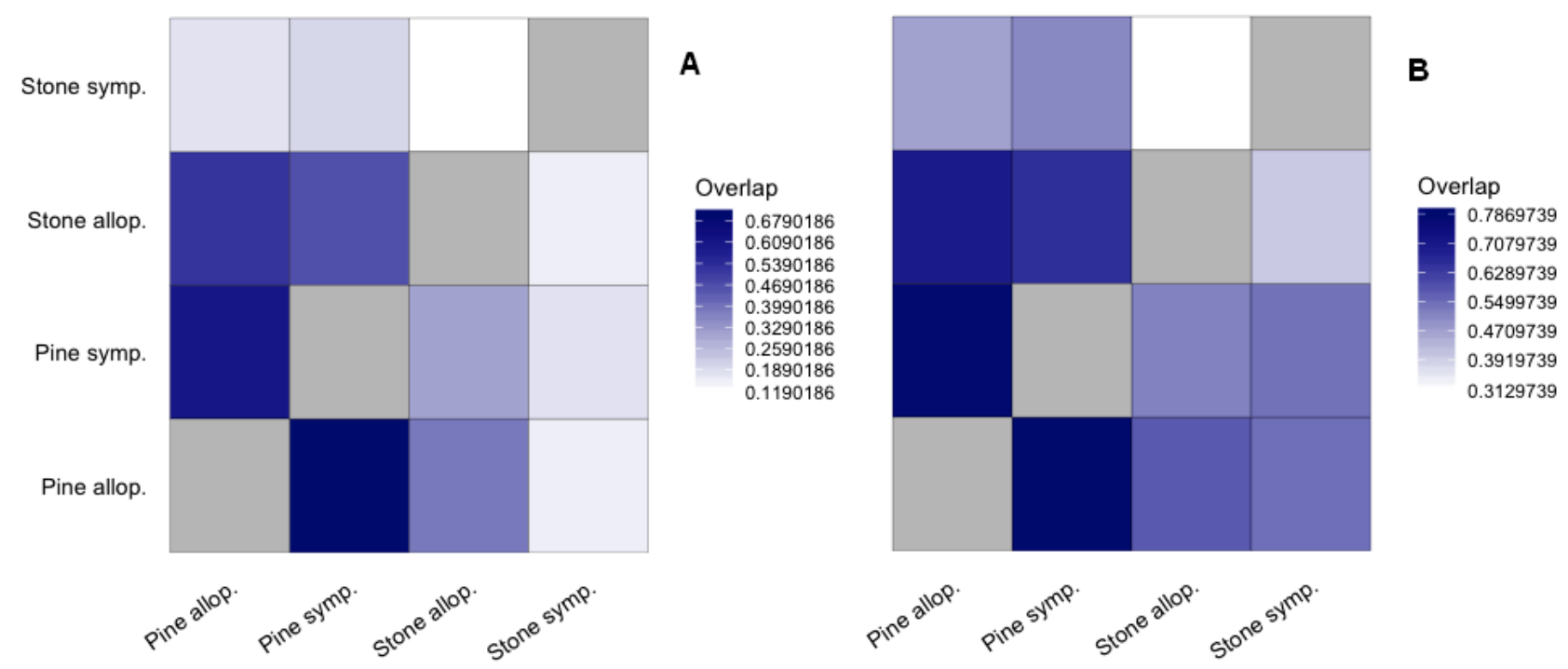

Figure 2. Nutritional niche overlap of pine- and stone marten in different conditions (sympatry vs. allopatry), as calculated using dynamic range boxes and the aggregation methods 'product' (A) and 'mean' (B). Heatmaps depict the overlaps port $(a, b)$ between the nutrient spaces of species $a$ and $b$ based on $n=3$ macronutrients. Light colours indicate little or no overlap. 
Figure S1. Distribution of the 32 reviewed study areas in Europe (letters and numbers correspond to those in Tab. 1).

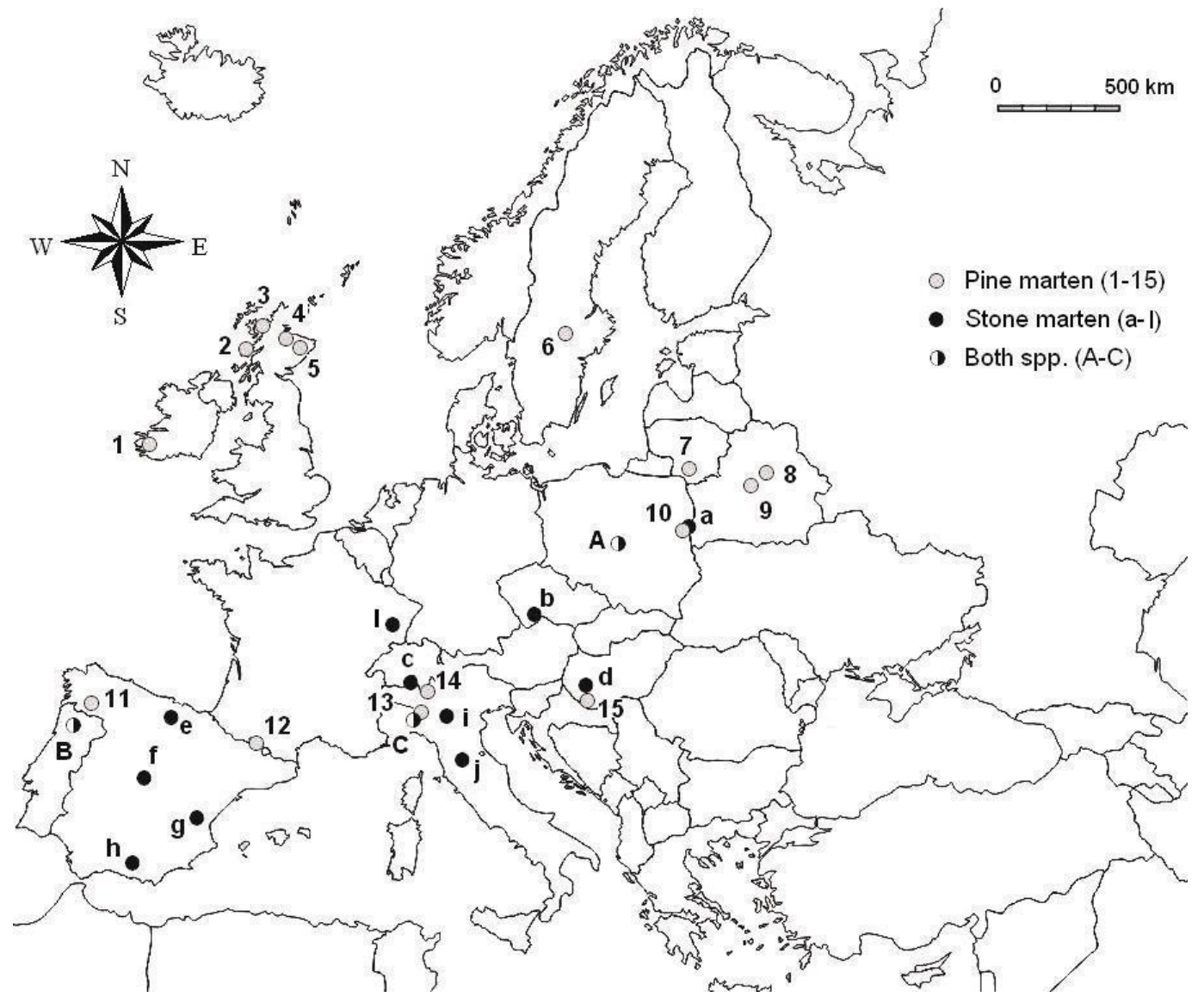

Figure S2. Sizes ( $\mathrm{ol}$ ) of nutritional spaces of pine- and stone marten in different conditions (sympatry vs. allopatry).

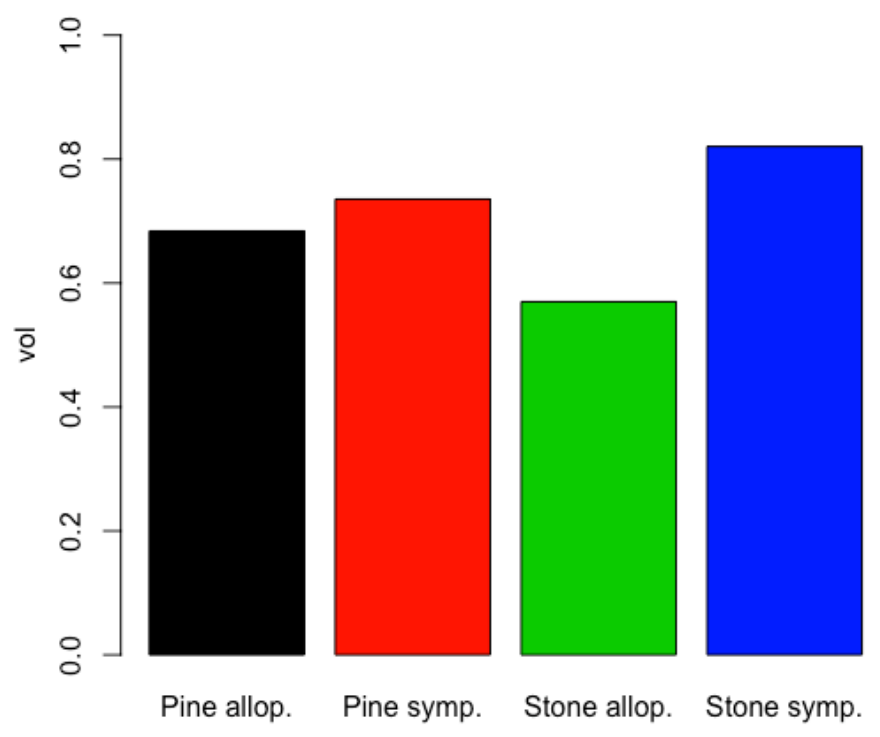


Table S1. Macronutrient content of martens' food resources.

\begin{tabular}{|c|c|c|c|}
\hline Food items & Protein & Lipids & Carbohydrates \\
\hline Fungi & 3.9 & 0.7 & 0 \\
\hline Fruit & 1.1 & 0.9 & 18.1 \\
\hline Wild Rosaceae & 1.6 & 0.5 & 18.5 \\
\hline Rubus spp. & 1.3 & 0 & 5.7 \\
\hline Rosa spp. & 1.6 & 0.3 & 38.2 \\
\hline Prunus spp. & 0.5 & 0.1 & 10.5 \\
\hline Sorbus aucuparia & 2.3 & 2.0 & 14.1 \\
\hline Crataegus monogyna & 2.5 & 0.0 & 24.2 \\
\hline Cultivated Rosaceae & 0.4 & 0.3 & 10.0 \\
\hline Mespilus germanica & 0.4 & 0.4 & 6.1 \\
\hline Prunus domestica & 0.7 & 0.3 & 11.4 \\
\hline Malus communis & 0.3 & 0.1 & 13.7 \\
\hline Pirus communis & 0.3 & 0.4 & 8.9 \\
\hline Diospyros kaki & 0.6 & 0.3 & 17.0 \\
\hline Hedera ilex & 1.8 & 5.1 & 21.0 \\
\hline Arbutus unedo & 1.0 & 0.0 & 11.0 \\
\hline Vaccinium spp. & 0.9 & 0.2 & 5.1 \\
\hline Ribes spp. & 0.9 & 0.0 & 6.6 \\
\hline Vitis vinifera & 0.5 & 0.1 & 13.5 \\
\hline Ficus carica & 0.8 & 0.3 & 19.2 \\
\hline Taxus baccata & 2.1 & 3.9 & 5.6 \\
\hline Castanea sativa & 1.8 & 2.9 & 39.4 \\
\hline Juniperus communis & 0.5 & 0.5 & 80.0 \\
\hline Earthworms & 11.8 & 1.5 & 0.0 \\
\hline Insects & 20.3 & 8.6 & 0.0 \\
\hline Larvae & 17.8 & 13.3 & 0.0 \\
\hline Reptiles & 19.8 & 3.7 & 0.0 \\
\hline Amphibians & 18.3 & 3.7 & 0.0 \\
\hline Birds & 21.7 & 5.4 & 0.1 \\
\hline Mammals & 19.7 & 8.5 & 0.0 \\
\hline Lepus europaeus & 21.8 & 2.3 & 0.0 \\
\hline Oryctolagus cuniculus & 20.0 & 4.0 & 0.0 \\
\hline Insectivores & 19.2 & 5.9 & 0.0 \\
\hline Rodents & 19.8 & 9.0 & 0.0 \\
\hline Hystrix/Myocastor & 20.1 & 10.2 & 0.0 \\
\hline Small rodents & 19.6 & 8.1 & 0.0 \\
\hline Rattus sp. & 20.1 & 10.2 & 0.0 \\
\hline Wild ungulates & 22.3 & 2.9 & 0.0 \\
\hline Livestock (beef and sheep) & 19.0 & 15.0 & 0.0 \\
\hline Carnivores & 15.5 & 16.9 & 0.0 \\
\hline Eggs & 13.0 & 11.0 & 0.4 \\
\hline Trout Salmo trutta & 1.7 & 14.7 & 3.0 \\
\hline Garbage & 10.5 & 3.1 & 8.8 \\
\hline
\end{tabular}


Table S2. Macronutrient (protein, lipids and carbohydrates) intakes of pine- (PM) and stone martens (SM), as assessed for the 32 selected studies. Data are expressed as percentage of metabolizable energy (N: sample size; codes correspond to those in Figure S1).

\begin{tabular}{|c|c|c|c|c|c|c|c|c|}
\hline Spp. & $\mathbf{N}$ & Protein & Lipids & Carboh. & code & Range & Habitat & References \\
\hline \multirow{18}{*}{$\mathbf{P M}$} & 335 & 52.8 & 38.9 & 8.3 & 7 & \multirow{7}{*}{ allopatry } & mosaic & Baltrunaite 2002 \\
\hline & 2449 & 47.7 & 41.5 & 10.8 & 4 & & forest & Caryl et al. 2012 \\
\hline & 760 & 52.1 & 40.1 & 7.7 & 6 & & forest & Helldin 2000 \\
\hline & 546 & 57.8 & 40.5 & 1.7 & 5 & & forest & Kubasiewicz 2014 \\
\hline & 337 & 52.3 & 38.4 & 9.3 & 3 & & forest & Lockie 1960 \\
\hline & 387 & 33.9 & 42.2 & 23.9 & 1 & & forest & Lynch \& McCann 2007 \\
\hline & 164 & 48.3 & 41.1 & 10.5 & 2 & & forest & Putman 2000 \\
\hline & 109 & 48.9 & 37.4 & 13.7 & 13 & \multirow{11}{*}{ sympatry } & agriculture & Balestrieri et al. 2011 \\
\hline & 148 & 47.7 & 39.3 & 12.9 & 14 & & forest & Biancardi \& Rinetti 2002 \\
\hline & 1735 & 51.8 & 47.1 & 1.1 & 10 & & forest & Jedrzejewski et al. 1993 \\
\hline & 332 & 53.0 & 42.3 & 4.7 & 15 & & forest & Lanszki et al. 2007 \\
\hline & 97 & 33.6 & 30.8 & 35.6 & $\mathrm{~B}$ & & forest & Monterroso et al. 2016 \\
\hline & 155 & 49.6 & 43.3 & 7.1 & A & & mosaic & Posluzny et al. 2007 \\
\hline & 109 & 50.1 & 39.6 & 10.3 & $\mathrm{C}$ & & agriculture & Remonti et al. 2012 \\
\hline & 198 & 47.7 & 39.7 & 12.6 & 11 & & forest & Rosellini et al. 2007 \\
\hline & 445 & 44.4 & 43.6 & 11.9 & 12 & & forest & Ruiz-Olmo \& Lopez-Martin 1996 \\
\hline & 1222 & 54.9 & 39.4 & 5.7 & 8 & & forest & Sidorovich et al. 2005 \\
\hline & 1624 & 54.1 & 39.6 & 6.3 & 9 & & forest & Sidorovich et al. 2010 \\
\hline \multirow{14}{*}{ SM } & 181 & 50.1 & 37.6 & 12.2 & $\mathrm{i}$ & \multirow{6}{*}{ allopatry } & agriculture & Balestrieri et al. 2013 \\
\hline & 194 & 48.5 & 47.9 & 3.6 & $\mathrm{c}$ & & forest & Balestrieri et al. 2018 \\
\hline & 140 & 52.4 & 38.5 & 9.1 & $\mathrm{f}$ & & forest & Barrientos \& Virgos 2006 \\
\hline & 157 & 48.3 & 37.8 & 13.8 & $\mathrm{e}$ & & mosaic & Delibes 1978 \\
\hline & 856 & 45.2 & 37.0 & 17.8 & $\mathrm{~h}$ & & forest & Padial et al. 2002 \\
\hline & 137 & 52.1 & 33.6 & 14.3 & $\mathrm{~g}$ & & forest & Such \& Calabuig 2002 \\
\hline & 984 & 38.9 & 29.9 & 31.2 & $\mathrm{a}$ & \multirow{8}{*}{ sympatry } & forest & Czernick et al. 2016 \\
\hline & 320 & 44.1 & 38.7 & 17.2 & $\mathrm{j}$ & & forest & Genovesi et al. 1996 \\
\hline & 1227 & 34.6 & 33.9 & 31.5 & $\mathrm{~d}$ & & agriculture & Lanszki et al. 2009 \\
\hline & 73 & 36.1 & 36.3 & 27.7 & B & & forest & Monterroso et al. 2016 \\
\hline & 287 & 36.6 & 32.8 & 30.6 & A & & mosaic & Posluzny et al. 2007 \\
\hline & 106 & 39.5 & 31.2 & 29.2 & $\mathrm{C}$ & & agriculture & Remonti et al. 2012 \\
\hline & 108 & 51.6 & 42.0 & 6.5 & $\mathrm{~b}$ & & agriculture & Rysava-Novakova \& Koubek 2009 \\
\hline & 326 & 43.2 & 41.4 & 15.4 & 1 & & mosaic & Waetcher 1975 \\
\hline
\end{tabular}


bioRxiv preprint doi: https://doi org/10.1101/599084; this version posted April 4, 2019. The copyright holder for this preprint (which was not certified by peer review) is the author/funder, who has granted bioRxiv a license to display the preprint in perpetuity. It is made available under aCC-BY-NC-ND 4.0 International license.

\section{References (Supplementary)}

Balestrieri A, Remonti L, Ruiz-González A, Vergara M, Capelli E, Gómez-Moliner BJ, Prigioni C 2011 Food habits of genetically identified pine martens (Martes martes) expanding in agricultural lowlands (NW Italy). Acta Theriol. 56, 199-207.

Balestrieri A, Remonti L, Capra RB, Canova L, Prigioni C 2013 Food habits of the stone marten (Martes foina) (Mammalia: Carnivora) in plain areas of Northern Italy prior to pine marten (M. martes) spreading, It. J. Zool. 80, 60-68.

Balestrieri A, Mosini A, Saino N 2018 Distribuzione ed ecologia di martora e faina nel Parco Nazionale della Val Grande. Technical report, University of Milan.

Baltrūnaite L 2002 Diet composition of the red fox (Vulpes vulpes L.), pine marten (Martes martes L.) and raccoon dog (Nyctereutes procyonoides Gray) in clay plain landscape, Lithuania. Acta Zool. Lituanica 12, 362-368.

Barrientos R, Virgós E 1996 Reduction of potential food interference in two sympatric carnivores by sequential use of shared resources. Acta Oecol. 30, 107-116.

Biancardi CM, Rinetti L 2001 The feeding habits of the pine marten Martes martes (L., 1758) (Mammalia, Mustelidae) in northern Luino area (northern Italy). Atti Soc. It. Sci. Nat. e Museo Civ. Storia Nat. Milano 142, 165-172.

Caryl FM, Raynor R, Quine CP, Park KJ 2012 The seasonal diet of British pine marten determined from genetically identified scats. J. Zool. 288, 252-259.

Czernik M, Kowalczyk R, Zalewski A 2016 Spatio-temporal variation of predator diet in a rural habitat: stone martens in the villages of Białowieża forest. Mamm. Res. 61, 187-196.

Delibes M 1978 Feeding habits of the stone marten Martes foina, in northern Burgos, Spain. Z. Säugetierk. 43, 282-288.

Genovesi P, Secchi M, Boitani L 1996 Diet of stone marten: an example of ecological flexibility. J. Zool. Lond. 238, 545-555.

Helldin JO 2000 Seasonal diet of pine marten Martes martes in southern boreal Sweden. Acta theriol. 45, 409-420.

Jędrzejewski W, Zalewski A, Jędrzejewska B 1993 Foraging by pine marten Martes martes in relation to food resources in Białowieża National Park, Poland. Acta Theriol. 38, 405-426.

Kubasiewicz LM 2014 Monitoring European pine martens (Martes martes) in Scottish forested landscapes. Thesis submitted for the degree of Doctor of Philosophy Biological \& Environmental Sciences, School of Natural Sciences, The University of Stirling.

Lanszki J, Zalewski A, Horváth G 2007. Comparison of red fox Vulpes vulpes and pine marten Martes martes food habits in a deciduous forest in Hungary. Wildl. Biol. 13, 258-271.

Lanszki J, Sárdi B, Széles GL 2009 Feeding habits of the stone marten (Martes foina) in villages and farms in Hungary. Natura Somogyiensis 15, 231-246.

Lockie JD 1960 The food of the pine marten Martes martes in west Ross-shire, Scotland. Proc. Zool. Soc. Lond. 136, 187-195.

Lynch AB, McCann Y 2007 The diet of the pine marten (Martes martes) in Killarney National Park. Proc. R. Irish Acad. Biol. Environ. 107B,67-76.

Monterroso P, Rebelo P, Alves PC, Ferreras P 2016 Niche partitioning at the edge of the range: a multidimensional analysis with sympatric martens. J. Mammal. 97, 928-939.

Padial JM, Ávila E, Gil-Sánchez JM 2002 Feeding habits and overlap among red fox (Vulpes vulpes) and stone marten (Martes foina) in two Mediterranean mountain habitats. Mammal. Biol. 67, 137-146.

Posluszny M, Pilot M, Goszczynski J, Gralak B 2007 Diet of sympatric pine marten (Martes martes) and stone marten (Martes foina) identified by genotyping of DNA from faeces. Ann. Zool. Fenn. 44: 269-284.

Putman, RJ 2000 Diet of pine martens Martes martes L. in west Scotland. J. Nat. Hist. 34, 793-797.

Remonti L, Balestrieri A, Ruiz-González A, Gómez-Moliner BJ, Capelli E, Prigioni C 2012 Intraguild dietary overlap and its possible relationship to the coexistence of mesocarnivores in intensive agricultural habitats. Popul. Ecol. 54, 521-532.

Rosellini S, Barja I, Piñeiro A 2007. Distribution and feeding habits of the Pine marten (Martes martes) at Os Montes do Invernadeiro Natural Park (Galicia, NW Spain). Galemys 19, 99-114. 
bioRxiv preprint doi: https://doi org/101101/599084 this version posted April 4, 2019. The copyright holder for this preprint (which was not certified by peer review) is the author/funder, who has granted bioRxiv a license to display the preprint in perpetuity. It is made available under aCC-BY-NC-ND 4.0 International license.

Ruiz-Olmo J., López-Martín JM 1996 Seasonal food of pine marten (Martes martes L., 1758) in a fir forest of Pyrenean mountains (northeastern Spain). Proceedings of the I European Congress of Mammalogy, Museu Bocage, Lisboa, pp. 189-198.

Ryšavá-Nováková M, Koubek P 2009 Feeding habits of two sympatric mustelid species, European polecat Mustela putorius and stone marten Martes foina, in the Czech Republic. Folia Zool. 58, 66-75.

Sidorovich VE, Krasko DA, Dyman AA 2005 Landscape-related differences in diet, food supply and distribution pattern of the pine marten, Martes martes in the transitional mixed forest of northern Belarus. Folia Zool. 54, 39-52.

Sidorovich VE, Sidorovich AA, Krasko DA 2010 Effect of felling on red fox (Vulpes vulpes) and pine marten (Martes martes) diets in transitional mixed forest in Belarus. Mamm. Biol. 75, 399-411.

Such A, Calabuig G 2002 Dieta de la garduña (Martes foina Erxleben, 1777) en la Serra de la Solana (Sur del País Valencià). Galemys 15, 167-180.

Waechter A 1975 Ecologie de la Fouine en Alsace. Rev. Ecol. Terre-Vie 29, 399-457. 